\title{
Edifice collapse and related hazards in Guatemala
}

\author{
James W. Vallance ${ }^{\mathrm{a}}$, Lee Siebert ${ }^{\mathrm{b}}$, William I. Rose Jr. a, Jorge Raul Girón ${ }^{1, \mathrm{c}}$, \\ Norman G. Banks ${ }^{\text {d }}$ \\ a Department of Geological Engineering and Sciences, Michigan Technological University, Houghton, MI 49931, USA \\ ${ }^{-}$Global Volcanism Program. Smithsonian Institution, NHB 119, Washington, DC 20560, USA \\ 'Sección Vulcanología, INSIVUMEH (Instituto Nacional de Sismología, Vulcanología, Meteorolgía, e Hidrología), 7 a Avenida, Zona 13, \\ Guatemala City, Guatemala \\ 'U.S. Geological Survey, 5400 MacArthur Blvd., Vancouver, WA 98661, USA
}

Received 21 January 1993; accepted 7 July 1994

\begin{abstract}
Guatemalan volcanoes have at least seven debris-avalanche deposits, associated with Cerro Quemado, Fuego, Pacaya, Tecuamburro and an unidentified volcano. The deposits range in size from less than 0.1 to in excess of $9 \mathrm{~km}^{3}$ and from 2.5 to in excess of $300 \mathrm{~km}^{2}$. The avalanches traveled 3 to $50 \mathrm{~km}$ from their sources in the Guatemalan highlands. Three of the avalanches occurred in Late Pleistocene time and four in Holocene time-two of them within the last 2000 years. The avalanches occurred at both andesitic and basaltic stratovolcanoes and at dacitic dome complexes. Laterally directed phreatic or magmatic pyroclastic explosions were associated with two of the debris avalanches.

An evaluation of factors that might lead to an edifice collapse in Guatemala is based on the case studies presented in this report and a survey of the literature. Edifice collapses are more apt to occur if zones of weakness exist within the volcanic edifices, such as unwelded pyroclastic rocks and pervasively altered rocks. Further, the trench-ward side of volcano pairs like Fuego and Atitlán may be more likely to fail because it may have weak zones along the contact with the older back-arc volcano. The direction of failure may be influenced by regional slopes, which in Guatemala generally trend southward toward the oceanic trench, and by such structural factors as multiple vents or overly steep slopes reflecting previous activity or erosion. Debris avalanches are more likely to occur in drainages which have headwaters at two or more volcanoes. Domes are especially apt to produce small- to moderate-sized debris avalanches, and, further, if the domes form a coalescing chain, are most likely to fail in a direction normal to the chain. These factors are used at seventeen major volcanic centers in Guatemala to assess their potential for edifice collapse and most probable direction of failure.
\end{abstract}

\section{Introduction}

The Guatemalan volcanic front trends east-southeast from Mexico to El Salvador and includes more than fifteen stratovolcanoes, as well as numerous more silicic volcanoes, especially dome complexes and calderas (Fig. 1). The stratovolcanoes rise $2000-4000 \mathrm{~m}$

\footnotetext{
' Present address: Comité Nacional de Emergencia, Guatemala City, Guatemala.
}

above the 50-60-km-wide, Pacific coastal plain, and 500-2000 $\mathrm{m}$ above the Guatemalan highlands (Fig. 1).

Seven Guatemalan volcanoes have erupted during historical times (since about 1540 A.D.), and Santiaguito, Fuego and Pacaya volcanoes have erupted repeatedly within the 20th century. Eruptions of these volcanoes have produced lava flows (Eichelberger and McGetchin, 1976), tephra falls (Rose et al., 1978; Williams and Self, 1983), pyroclastic flows (Rose et al., 


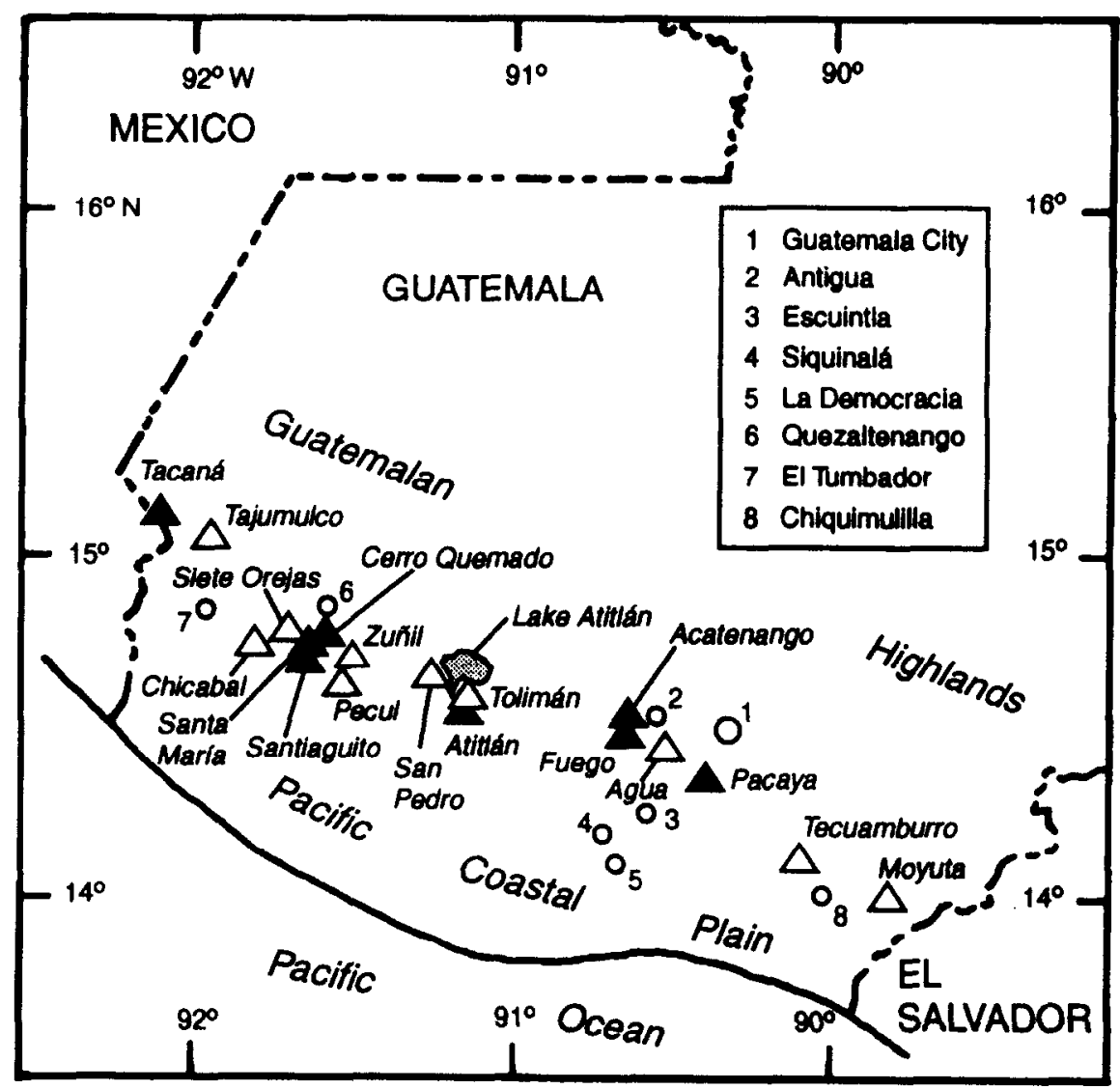

Fig. I. Index map of Guatemala showing the volcanic arc. $\Delta$ indicates historically active volcano; $\Delta$ indicates dormant volcano.

1977; Davies et al., 1978) and lahars (Bonis and Salazar, 1973; Vessell and Davies, 1981). Some of these events have resulted in fatalities and extensive property damage.

The 1980 eruption of Mount St. Helens led to an increased awareness of hazards from collapse of volcanic edifices (Voight et al., 1981, 1983). These catastrophic events have caused more than 20,000 fatalities in the past 400 years (Siebert et al., 1987). No large edifice collapses of Guatemalan volcanoes have occurred historically, but prehistoric events have occurred repeatedly. This study examines the characteristics, origin, distribution and frequency of edifice collapses in Guatemala, and provides a regional assessment of hazards from such events.

\subsection{Volcanic edifice collapse and its products}

Volcanic edifice collapses produce scars that vary from shallow spoon-shaped scarps to huge horseshoe- shaped amphitheaters several kilometers wide. Some large avalanche scarps could be confused with collapse calderas that have been breached by erosion of rivers; there are, however, differences. The sidewalls of avalanche amphitheaters are subparallel or widen in the downstream direction; in contrast, the walls of erosionally breached calderas commonly narrow in the downstream direction (Siebert, 1984). The sizes of avalanche scarps and calderas overlap, but most collapse calderas are larger. Avalanche scarps average from 1 to $3 \mathrm{~km}$ in width, whereas calderas average 6 $\mathrm{km}$ in diameter and can be tens of kilometers wide (Siebert, 1984). Volcanic edifice collapses can occur in association with magmatic eruptions, as at Bezymianny in 1956 and Mount St. Helens in 1980, or without eruptions as at Unzen in 1792 (Siebert et al., 1987).

An edifice collapse commonly generates a large volcanic debris avalanche. A debris avalanche is a sudden, rapid flowage of wet or dry, incoherent, unsorted 
mixtures of rock and matrix in response to gravity (Schuster and Crandell, 1984). Although the debris can contain significant moisture, much of it is unsaturated. A debris-avalanche deposit is characterized by its irregular hummocky topography, which may exhibit mounds, closed depressions, large transverse ridges and lateral levees (Voight et al., 1981, 1983; Glicken, 1986). Some debris avalanches contain enough moisture to dewater and form debris flows. Debris flows having this origin flowed several tens of kilometers downstream from the 1980 debris avalanche at Mount St. Helens (Janda et al., 1981). In this report a debris flow is a water-saturated mixture of rock and debris moving down slope under the influence of gravity and having a solids fraction of at least $80 \%$ by weight or $60 \%$ by volume. A lahar is a debris flow at a volcano.

An edifice collapse can also transform directly to a debris flow. Crandell (1971) and Scott et al. (1992) noted five Holocene debris flows having this origin at Mount Rainier and Vallance (1994) noted two others at Mount Adams. Collapses are more likely to become debris flows when they contain hydrothermal clay which is capable of holding a large volume of pore water. Volcanoes which have hydrothermally altered summit regions are more likely sites for debris flows of this type. Avalanche-induced debris flows have greater mobility and may flow further than debris avalanches of similar size.

Laterally directed explosions commonly result when the overburden of a phreatic or magmatic system is removed by avalanching so that sudden decompression occurs. The explosions produce rapidly moving, highly inflated pyroclastic density currents that are termed laterally directed blasts (Crandell and Hoblitt, 1986). Laterally directed blasts have significant low-angle components directed in arcs of $180^{\circ}$ or less (Crandell and Hoblitt, 1986), and can spread over large areas regardless of intervening topography, leaving behind only thin deposits which may have the characteristics of both pyroclastic flow and pyroclastic surge deposits. The Mount St. Helens blast moved at speeds in excess of $300 \mathrm{~m} / \mathrm{s}$ (Kieffer, 1981), devastated about $600 \mathrm{~km}^{2}$ and produced deposits with four-unit stratigraphy (Hoblitt et al., 1981).

\section{Avalanche and laterally directed blast deposits in Guatemala}

Based on Skylab photography, Rose et al. (1975) identified two poorly vegetated fans south of Escuintla and south of Chiquimulilla as possible volcanic lahar or avalanche fans. The results of our study show that the fan near Escuintla is entirely formed of a Pleistocene debris-avalanche deposit and that the fan near Chiquimulilla is largely covered by Holocene and Pleistocene alluvial debris, but might conceal another debris-avalanche deposit. During a preliminary hazard assessment of Pacaya Volcano, Banks (1986) noted the existence of a debris-avalanche deposit along Río Metapa (which drains south-southwest from Pacaya volcano) and indicated Pacaya volcano as its source. Our current work confirms this conclusion. In addition, we have mapped a third debris-avalanche deposit, probably from an unidentified volcano near Fuego volcano, in the coastal plain south of Siquinalá and west of La Democracia. In the highlands, three debris-avalanche deposits lie adjacent to Tecuamburro volcano (Duffield et al., 1989), and another is north of the Cerro Quemado dome complex (Vallance et al., 1989; Conway et al., 1992).

\subsection{Pacaya volcano}

Pacaya is a basaltic stratovolcano located at the southern edge of the Amatitlán caldera that has erupted repeatedly from several vents during historical times, producing tephra falls and lava flows (Fig. 2). The Mackenney cone, active since 1961, is built within the avalanche scarp of an ancestral stratovolcano (Fig. 2). Both the modern and the ancestral cones are Holocene (Eggers, 1971) and comprise interbedded lava, tephra and tuff, all formed of distinctive porphyritic olivine basalt with abundant euhedral plagioclase phenocrysts as large as $2 \mathrm{~cm}$. Volcanism at Pacaya is apparently episodic, with eruptive intervals of about $50-300 \mathrm{yr}$, during which large volumes of basaltic lava and scoria are erupted, and longer dormant intervals of about 300500 yr (Conway et al., 1992). Sometime between 400 and $2000 \mathrm{yr}$ B.P., the typical Strombolian eruptive pattern at Pacaya was interrupted by a sector collapse, and phreatic to phreatomagmatic explosions that we infer caused laterally directed surges. 
A

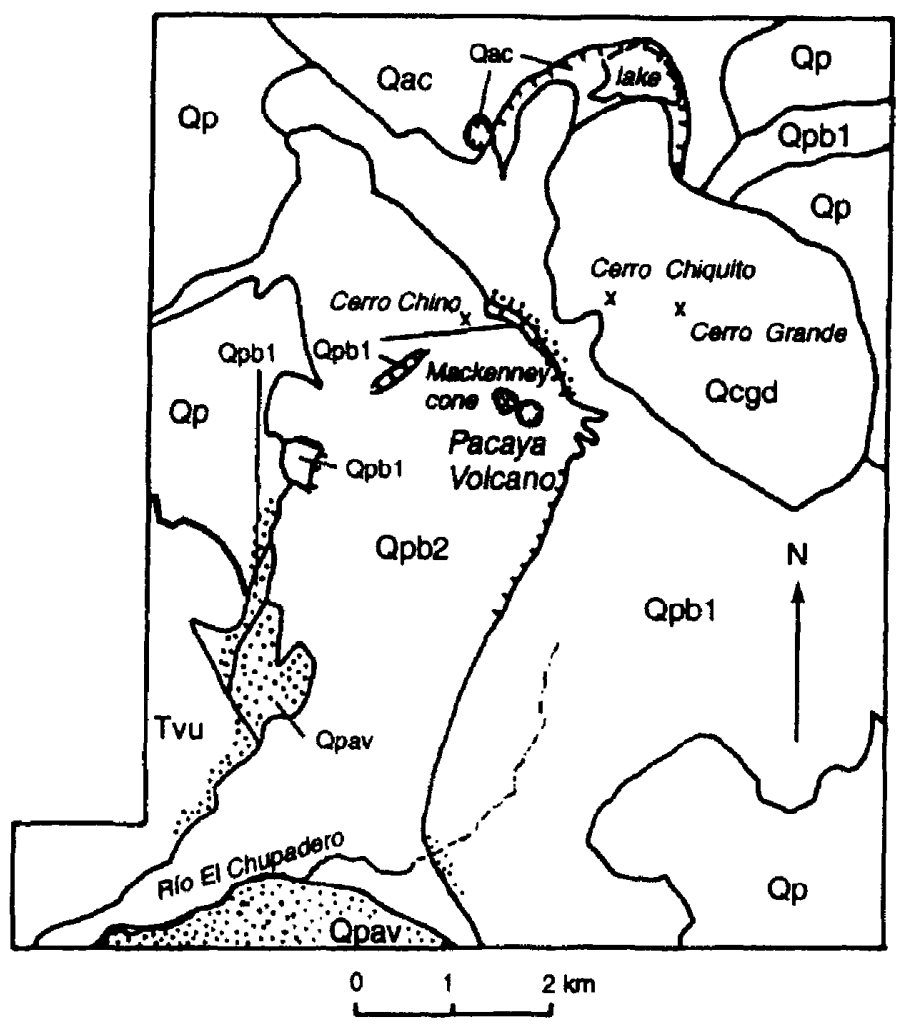

B

Schematic cross section

NNW

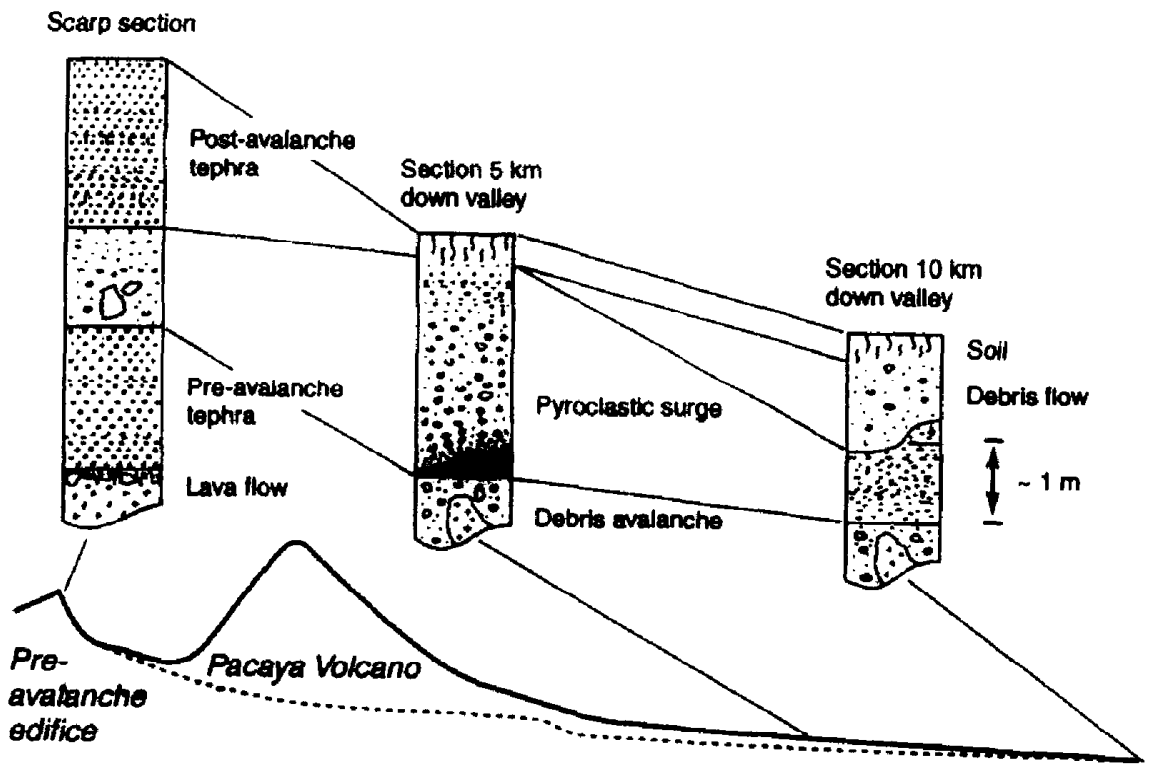


A horseshoe-shaped amphitheater, now partially filled by the post-avalanche Pacaya volcano, is the source of an avalanche that underlies the Río Metapa valley and part of the Pacific coastal plain (Figs. 2 and 3). Eggers $(1971,1975)$ ) suggested that the amphitheater scarp is a caldera collapse fault, but several lines of evidence suggest that the scarp resulted from gravitational collapse. First, the debris avalanche can be traced to within $2 \mathrm{~km}$ of Pacaya volcano. Second, based on hand sample, thin section and XRF analysis, the porphyritic olivine basalt, common in the avalanche deposit, is identical with lavas in the amphitheater scarp, indicating that the scarp is a likely source. Third, the missing volume of the ancestral volcano, if it was not more than about $200 \mathrm{~m}$ higher than Pacaya is now, would be about $0.6 \mathrm{~km}^{3}$-about the same volume as that of the debris avalanche. Last, there are no correlative pyroclastic-flow and tephra deposits of a volume to suggest caldera collapse.

The inferred events encompassing the edifice collapse are: (1) a period of Strombolian activity typical of Pacaya, including eruption of numerous thin lava flows that mantled the ancestral cone; (2) edifice collapse and subsequent debris avalanche; (3) a sequence of phreatic and phreatomagmatic explosions, directed laterally toward the south-southwest, which occurred during or shortly after the avalanche; and (4) subsequent return to Strombolian activity and building of the modern cone.

The age of the Pacaya avalanche and surge deposits is constrained by the absence of historical accounts and the extent of soil development. Because there is no historical record of the avalanche, it must predate European settlement of the area between the middle of the 16 th century and the beginning of the 17 th century. The primitive soils on the avalanche and blast deposits, which are $20-40 \mathrm{~cm}$ thick and lack authogenic or mechanically infiltrated clay, indicate a late Holocene age (White and Valastro, 1984; Birkeland, 1984). These soils are similar to but somewhat less developed than the 1-m-thick soil developed on a lahar deposit near Escuintla. Edwin Shook identified pottery shards of the early Late Pre-classical Period (300 B.C. to 0 A.D.) that were found under the lahar deposit (Hunter, 1976). We infer that the debris-avalanche deposit is younger than the lahar deposit and thus has an age between about 2000 and 400 yr B.P.

The debris-avalanche deposit underlies about $55 \mathrm{~km}^{2}$ of the Río Metapa valley between its source at Pacaya volcano and an area about $3 \mathrm{~km}$ south of Las Chapernas-a total distance along the valley of $25 \mathrm{~km}$ (Fig. 3). Near Pacaya volcano, younger lava flows overlie the avalanche deposit, but just beyond this area, abundant hummocks occupy the valley (Fig. 2). On a ridge about $180 \mathrm{~m}$ above Río El Chupadero, a tributary of Río Metapa, between Finca La Suiza and Finca Buenos Aires (Fig. 3) a hummock formed of Pacaya basalt indicates that the avalanche overtopped the ridge and flowed into an adjacent tributary of Río Metapa. Deposits on valley sides indicate that the avalanche filled the upper Río Metapa valley system to depths of between 50 and $120 \mathrm{~m}$. Where Río Metapa emerges onto the coastal plain near Las Chapernas, the avalanche deposit forms a $20 \mathrm{~km}^{2}$ lobe about $4 \mathrm{~km}$ wide and $8 \mathrm{~km}$ long (Fig. 3). The debris-avalanche deposit is characterized by numerous hummocks in both upland valleys and on the Las Chapernas lobe. Hummocks generally vary between 5 and $10 \mathrm{~m}$ high, but may be as high as $15 \mathrm{~m}$ about $2 \mathrm{~km}$ west of Los Pocitos and $5 \mathrm{~km}$ south of Pacaya volcano. Near the distal margin of the Las Chapernas lobe, the size and frequency of hummocks diminish.

The Las Chapernas lobe exhibits steep-sided margins that rise 5-10 $\mathrm{m}$ above the surrounding flood plain.

Fig. 2. Simplified geologic map and schematic cross section of Pacaya volcano and vicinity. (A) Map of general geology; bedrock units are modified from Eggers (1975). Units from oldest to youngest: $T v u=$ undifferentiated Tertiary volcanic and volcaniclastic rock; $Q p=$ is mostly rhyolitic to dacitic pumiceous tephra and ignimbrite, but also includes other undifferentiated volcanic rock; $Q p$ may comprise several units and thus be variable in age; $Q a c=$ andesitic to basaltic rock of the Laguna de Calderas volcano; $Q p b 1=$ basalt from the pre-avalanche edifice of Pacaya volcano; $Q c g d=$ primarily dacitic rock with abundant basaltic andesite inclusions from Cerro Grande and Cerro Chiquito (Bartintzeff and Deniel, 1992), and overlaps $Q p b 1$; Qpav = debris avalanche from Pacaya volcano-the stippled pattern indicates the distribution of contemporaneous pyroclastic-surge deposits; $Q p b 2=$ post-avalanche basalt from Pacaya volcano. Caldera or avalanche scarps are indicated by lines with hachures on the scarp side and craters are indicated by closed figures with small tics on the inside. (B) Schematic cross section from the pre-avalanche scarp, through modern Pacaya edifice and $10 \mathrm{~km}$ to the south-southwest down the Río Metapa drainage system. The longitudinal profile is not to scale. 


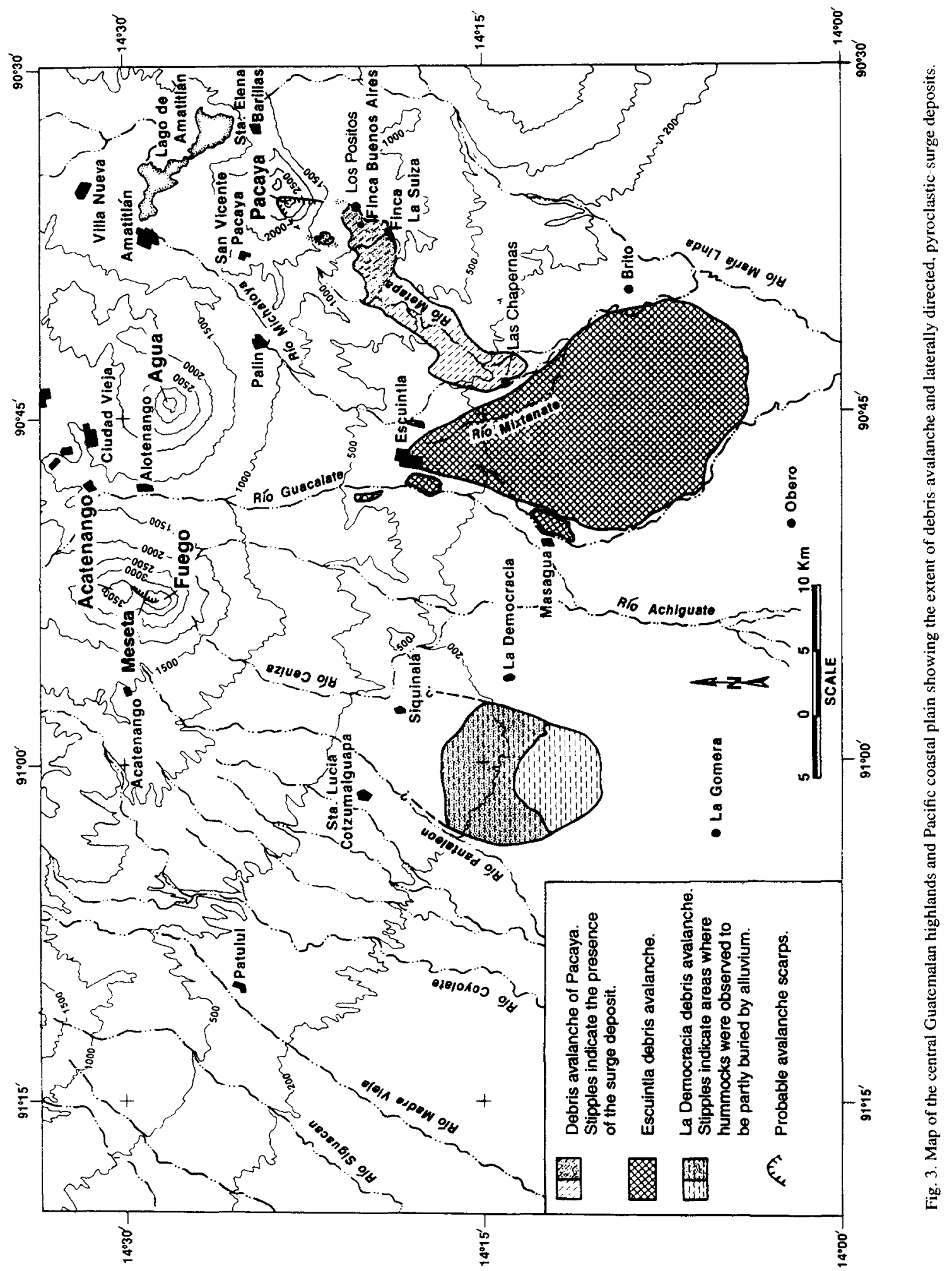


In the upper Río Metapa, large lateral levees up to 20 $\mathrm{m}$ high are present. These levees form natural dams for three small lakes along the western margin of the avalanche deposit. On steep valley sides, the avalanche deposit forms a veneer from 0.5 to $2 \mathrm{~m}$ thick.

Outcrops of the avalanche deposit exhibit angular to subangular pebble-, cobble- and boulder-size rocks in silty-sand matrix. Most outcrops have color variations on a scale of less than $1 \mathrm{~m}$ that suggest incompletely homogenized fragments of breccia and pyroclastic flows. Debris-avalanche blocks are mostly formed of fragmented basalt; however, many exposures exhibit large-scale units of the original volcano that were transported relatively intact but deformed to some extent. Numerous irregular pods of white, fibrous, biotite-bearing pumice occur in debris-avalanche blocks, and fragments of this pumice occur in mixed-facies (Glicken, 1991 ) exposures. The pumice is common at the surface of the deposit. It is probably derived from a thick tephra and ignimbrite sequence that draped the landscape prior to the formation of pre-avalanche Pacaya volcano (unit Qp, Fig. 2). Much of the pumice was probably incorporated by erosion during transport; however, blocks formed almost entirely of the pumice suggest that some of it could have come from deep parts of the original avalanche mass.

The most common lithology in the avalanche deposit is the striking porphyritic basalt, typical of Pacaya volcano. Other lithologies include finer-grained olivine basalt, volcanic rock of unknown origin and the abovementioned pumice. At several localities near the base of the deposit, abundant casts of wood fragments, which were incorporated in the avalanche, are visible, but none of the wood is preserved.

The thickness of the deposit at its margin near Las Chapernas is about $8 \mathrm{~m}$; however, the convex surface of the Las Chapernas lobe suggests a greater thickness toward the medial axis of the deposit. We estimate that the thickness of the Las Chapernas lobe averages $15 \mathrm{~m}$. The avalanche deposit in the Río Metapa valley is variable from $3 \mathrm{~m}$ to in excess of $15 \mathrm{~m}$ thick. If the Las Chapernas lobe and upland valley deposits have average thicknesses of 15 and $10 \mathrm{~m}$, then the avalanche has an approximate volume of $\left(15 \mathrm{~m} \times 20 \mathrm{~km}^{2}\right)+(10$ $\mathrm{m} \times 35 \mathrm{~km}^{2}$ ) $=0.65 \mathrm{~km}^{3}$.

The surge deposit discontinuously drapes the topography in a $90^{\circ}$ arc as far as $10 \mathrm{~km}$ south-southwest of Pacaya volcano (Figs. 2 and 3 ). The surge originally covered an area of at least $30 \mathrm{~km}^{2}$ near Pacaya and in the Río Metapa drainage basin (Fig. 3). Additional deposits may be present in $20 \mathrm{~km}^{2}$ of rugged terrain southwest of Pacaya, but we did not look for it there. The surge deposit is present in outcrops of the avalanche scarp to the north and east. If the surge deposit exists appreciably further from the scarp in those directions, it is now concealed by post-avalanche lava and tephra. The medial axes of the avalanche amphitheater and of the arc subtended by the distribution of known surge deposits almost exactly coincide, suggesting that the surge and avalanche were genetically related and that the surge was laterally directed to the south-southwest.

The lack of weathering between the surge and debrisavalanche deposits and the incorporation of avalanche material into the base of the surge unit are consistent with contemporaneous deposition or with deposition of the surge at a time before vegetation and significant soil were reestablished, perhaps as much as a few tens of years latcr. Inasmuch as phreatic and phreatomagmatic explosions like those represented by the surge deposit are atypical of Pacaya, it seems more probable that the surge is genetically related to the debris avalanche. Sudden disruption and decompression of a hot hydrothermal system and, subsequently, a magmatic system is consistent with the characteristics of the surge deposits described below.

Proximal surge deposits are thicker in swales and valleys than on hills and ridges and thicken on the stoss sides of obstacles in the path of flow. Low-angle dune forms and antidune cross bedding are common the lower half of many deposits. Medial and distal deposits in valley bottoms are commonly unconformably overlain by a poorly sorted, indurated diamicton having a matrix similar in appearance and texture to that of the surge deposit. The diamicton is likely to be a lahar subsequently derived from surge deposits. Distal surge deposits generally thin with distance from source and are commonly absent or not preserved on topographically high areas.

Along the avalanche scarp, the surge unit comprises a grayish-yellow, juvenile-rich layer containing angular scoriaceous basalt up to $5 \mathrm{~cm}$ in diameter on top of a phreatic, orange brown, poorly sorted diamicton containing angular clasts to $50 \mathrm{~cm}$ in a silty matrix (Fig. 2B). Basalt particles of juvenile origin are scarce in the lower half of the deposit. At one locality near twin 
cairns, surge deposits $20-40 \mathrm{~cm}$ thick underlie $60 \mathrm{~cm}$ of 1987 tephra, $40 \mathrm{~cm}$ of bomb-bearing tephra that is weathered to a depth of about $15 \mathrm{~cm}$, and $1.5 \mathrm{~m}$ of scoriaceous tephra with several $2-5 \mathrm{~cm}$ yellowish oxidized zones that suggest short weathering breaks. The surge overlies $2 \mathrm{~m}$ of unweathered scoriaceous tephra on top of a rubbly lava flow top that is weathered to a depth of about $10-20 \mathrm{~cm}$.

At a distance of $5 \mathrm{~km}$ south of Pacaya, the deposit is weathered to a depth of about $30 \mathrm{~cm}$ and overlies unweathered debris-avalanche deposit (Fig. 2B). At a locality near Finca Buenos Aires (Fig. 3), the surge deposit has three layers. The basal layer is lenticular, grayish-brown and composed of loosely packed sand and granules, apparently eroded from the debris avalanche. The 100-cm-thick, orangish-brown, second unit consists of angular pebbles and cobbles to $10 \mathrm{~cm}$ within a matrix of silt- to granule-sized ash, is inversely graded in its basal $15 \mathrm{~cm}$, and exhibits fine-grained, laminar partings near its upper contact. Twenty-five centimeters of undisturbed third layer are preserved, but an additional $40 \mathrm{~cm}$ is present, although its original texture is destroyed by weathering. The undisturbed part of the layer consists of pebbles to $1 \mathrm{~cm}$ in sandysilt-sized ash.

At distances of 5-10 km from Pacaya, exposures typically show two orange brown, phreatic surge units and an interbedded phreatomagmatic unit that has features of both a surge and a fall deposit (Fig. 2B). The basal unit has low-angle dune forms. It contains: material eroded from the underlying avalanche deposit; sparse angular, glassy Pacaya basalt pebbles up to $1 \mathrm{~cm}$ in diameter; and near its top, one or more horizons of accretionary lapilli. The second unit contains abundant cauliform basaltic scoria in addition to denser angular basalt and orangish-brown ash. The upper unit contains scoria fragments, discontinuous accretionary lapilli horizons, and a few pebbles incorporated from nearby surfaces.

\subsection{The Escuintla debris avalanche}

A debris-avalanche deposit forms a $300-\mathrm{km}^{2}$ lobe about $27 \mathrm{~km}$ long and up to $18 \mathrm{~km}$ wide south of Escuintla (Fig. 3). The greater part of the avalanche deposit was previously mapped as Tertiary volcaniclastic deposits of the Escuintla lobe, and several isolated parts were mapped as Tertiary volcanic rocks
(Hunter et al., 1984). The morphology, characteristics and stratigraphic relations of the unit indicate that it is a Late Pleistocene debris avalanche, which we call the Escuintla debris avalanche.

The Escuintla debris-avalanche deposit can be traced from $4 \mathrm{~km}$ north-northwest of Escuintla, where a small island of hummocky terrain is surrounded by younger alluvial fan deposits, to its terminus approximately 50 $\mathrm{km}$ from its probable source (Fig. 3). Two other remnants lie beyond the present western margin of the Escuintla fan. Active erosion of the Guacalate and Michatoya river systems has removed some of the northwestern and northeastern margins of the avalanche deposit. Because the avalanche deposit is not positively identified more than $4 \mathrm{~km}$ north of Escuintla, Fuego, Acatenango and Agua volcanoes are each possible as its source (Fig. 3).

Eight lava blocks, chosen for their textural variety, from several localities were selected for XRF analysis. The Escuintla debris-avalanche deposit contains volcanic rocks which range from 50 to $65 \% \mathrm{SiO}_{2}$ (Table 1). We compared the compositions of the avalanche blocks with chemical data on rocks from Fuego, Meseta (an older cone now mostly buried under the modern Fuego cone), Acatenango, and Agua volcanoes (Chesner and Rose, 1984; Carr and Rose, 1987). The compositional variety of rocks from the Escuintla avalanche deposit is similar to the variety demonstrated by the rock suites of Meseta, Acatenango and Agua but not to that of Fuego, which has historically produced only basaltic lavas.

Although the compositional data are compatible with any one of the three source volcanoes, two lines of evidence suggest that the avalanche deposit came from the Meseta cone. First, no collapse scar is now visible on Acatenango or Agua volcanoes, but Meseta has a prominent scarp partly covered by the younger Fuego volcano. Second, the Escuintla debris-avalanche fan is positioned east of the center of the complex of depositional fans south of Escuintla (Fig. 3); thus the debris avalanche would have had a straighter path between its source and its position on the Pacific coastal plain if Meseta or Acatenango were the source volcano, rather than Agua.

The characteristic morphology of the avalanche deposit includes a slightly convex cross-sectional profile and numerous hummocks varying in height from 5 $\mathrm{m}$ up to about $50 \mathrm{~m}$. The avalanche has resulted in a 
reversal of former topography, and major rivers now flow just beyond its distal margins. Along the apex of the avalanche lobe, there are alternating zones having varying hummock densities. The size and density of hummocks is greater in a $10-\mathrm{km}$-long segment south of Escuintla and in a band between 2 and $5 \mathrm{~km}$ from the lateral and distal margins of the deposit. Areas within 1-2 km of the distal margin and in the middle of the lobe have smaller hummocks and lower hummock densities. Debris-avalanche deposits commonly exhibit decreasing hummock size and density with increased distance from the source (Glicken, 1986; Crandell, 1989). The alternating distribution of hummocks within the Escuintla debris-avalanche deposit might have been the result of two (or more) nearly contemporaneous slide blocks-an initial large block that came to rest at the distal margin, and a second block that came to rest about $10 \mathrm{~km}$ south of Escuintla.

The hummocks contain huge blocks of basalt, andesite, and dacite breccia and lava, that are commonly fractured, faultcd and deformed. Some larger hummocks have horst-like structure in which normal faults en échelon dip steeply away from crests. Breccia schlieren are common along faults between breccia masses. In hummocks that contain several lithologies, largescale $(2-20 \mathrm{~m})$ color variations are visible. Incompletely mixed zones of variably colored breccia are present in many hummocks, forming color variations on a 1-m scale. Mixed-facies material, which is well exposed only at the flanks of the hummocks, comprises angular to subangular pebble-, cobble- and bouldersized basalt and andesite within silt and sand.

The thickness of the debris-avalanche deposit is not well known. The margins of the avalanche fan, however, exhibit approximately $20 \mathrm{~m}$ of relief in comparison with adjacent alluvial surfaces, and suggest a minimum thickness of $20 \mathrm{~m}$. Moreover, comparison of the two adjacent river plains with the medial axis of the Escuintla fan suggests at least $60 \mathrm{~m}$ of relief. The avalanche has a volume of at least $9 \mathrm{~km}^{3}$, using $30 \mathrm{~m}$ as a conservative estimate of the average thickness and would have had a much greater volume before proximal parts of it were eroded and buried.

The debris avalanche is older than the previously mentioned, 2000-yr-old lahar of Hunter (1976) that occupies the flood plain of the Guacalate River. Soil development on the deposit varies from $2 \mathrm{~m}$ thick at the top of hummocks to as thick as $5 \mathrm{~m}$ at the flanks of hummocks, indicating an age of tens of thousands of years (Mohr et al., 1973; Birkeland, 1984). Soils typically comprise 1-2 $\mathrm{m}$ of red laterite and about $2 \mathrm{~m}$ of intensely weathered avalanche debris. The Los Chocoyos tephra was not observed to overlie the avalanche deposit even though the ignimbrite crops out only 12 $\mathrm{km}$ west of Escuintla. Thus we postulate that the avalanche postdates the $84 \mathrm{ka}$ Los Chocoyos ash. Moreover, another ignimbrite, which represents either Los Chocoyos or an Amatitlán unit crops out about $5 \mathrm{~km}$ north of the avalanche deposit near the mountain front. By comparing eruption rates to edifice volumes, Chesner and Rose (1984) suggest that a minimum of about 8500 yr was required to build Fuego volcano. They also suggest that the Fuego-Meseta complex is probably not more than about $30,000 \mathrm{yr}$ old. If the Escuintla debris avalanche had an origin at Meseta, then its age is most likely between about 30,000 and 8500 yr B.P.

\subsection{The La Democracia debris avalanche}

About $5 \mathrm{~km}$ west of La Democracia, a debris-avalanche lobe about $10 \mathrm{~km}$ wide and $15 \mathrm{~km}$ long underlies about $120 \mathrm{~km}^{2}$ of the coastal plain (Fig. 3). Parts of the avalanche were mapped by Hunter et al. (1984) as Tertiary volcaniclastic rock. The shape, size and distribution of the hummocks, the variable lithology of the hummocks and the stratigraphic relations of the deposit suggest that it is a Late Pleistocene debris avalanche. The deposit has a volume of $2.4 \mathrm{~km}^{3}$ assuming a $20 \mathrm{~m}$ thickness, and a similar volume must now be buried or eroded by alluvial fan processes in its upstream reach.

The deposit can be traced northward from its terminus to within $5 \mathrm{~km}$ south of Siquinalá, where it is being buried by the actively aggrading Pantaleón fan system (Fig. 3). In the area south of Siquinalá, isolated mounds protrude through the alluvium. Further south, the surface is characterized by numerous hummocks up to $40 \mathrm{~m}$ high. The largest of these occur between the distal margin and $10 \mathrm{~km}$ up slope; the lack of larger hummocks further up slope probably reflects burial of the deposit near the active part of the alluvial fan.

The mounds are formed of blocks of basalt and basaltic andesite. One hummock exposed to a depth of $6 \mathrm{~m}$ exhibits weathering to at least that depth; nevertheless, we were able to collect relatively fresh clasts from the surfaces of several hummocks. Seven samples submitted for XRF analysis range from 51 to $53 \% \mathrm{SiO}_{2}$ (Table 
Table 1

Range of whole-rock chemical analyses by XRF

\begin{tabular}{lllll}
\hline & $\mathrm{E}$ & $\mathrm{LD}$ & $\mathrm{AG}$ & $\mathrm{MF}$ \\
\hline $\mathrm{SiO}_{2}$ & $50.4-65.7$ & $51.2-53.7$ & $54.6-61.4$ & $50.6-61.8$ \\
$\mathrm{TiO}_{2}$ & $0.44-1.03$ & $0.84-1.11$ & $0.69-0.98$ & $0.65-0.94$ \\
$\mathrm{Al}_{2} \mathrm{O}_{3}$ & $16.6-19.4$ & $18.2-20.5$ & $17.9-20.3$ & $18.6-20.9$ \\
$\mathrm{Fe}_{2} \mathrm{O}_{3}^{1}$ & $4.05-9.54$ & $6.74-10.6$ & $5.82-8.82$ & $5.15-10.5$ \\
$\mathrm{MnO}$ & $0.13-0.16$ & $0.12-0.16$ & $0.11-0.15$ & no data \\
$\mathrm{MgO}$ & $0.92-3.55$ & $1.65-3.78$ & $1.59-2.85$ & $2.19-4.46$ \\
$\mathrm{CaO}$ & $3.20-8.95$ & $7.40-9.34$ & $5.84-8.61$ & $5.26-9.42$ \\
$\mathrm{Na}{ }_{2} \mathrm{O}$ & $2.76-4.96$ & $2.86-3.47$ & $3.67-4.18$ & $3.30-4.59$ \\
$\mathrm{~K}_{2} \mathrm{O}$ & $0.90-2.19$ & $0.72-1.60$ & $1.24-1.98$ & $0.82-2.09$ \\
$\mathrm{P}_{2} \mathrm{O}_{5}$ & $0.17-0.24$ & $0.17-0.30$ & $0.23-0.31$ & $0.13-0.25$ \\
$\mathrm{~V}$ & $66-185$ & $179-222$ & $64-184$ & $54-242$ \\
$\mathrm{Cr}$ & 256 & $23-73$ & 217 & $2-120$ \\
$\mathrm{Ni}$ & $2-10$ & $3-22$ & $2-8$ & $2-57$ \\
$\mathrm{Rb}$ & $24-58$ & $14-20$ & $20-46$ & $6-55$ \\
$\mathrm{Sr}$ & $411-569$ & $493-596$ & $530-603$ & $594-869$ \\
$\mathrm{Y}$ & $16-29$ & $12-20$ & $19-21$ & $6-32$ \\
$\mathrm{Zi}$ & $143-197$ & $112-133$ & $143-193$ & $75-201$ \\
$\mathrm{Ba}$ & $340-781$ & $324-638$ & $461-667$ & $257-821$ \\
$\mathrm{Ni}$ & 9 & 7 & 10 & 35 \\
\hline
\end{tabular}

$E=8$ samples from the Escuintla debris avalanche; $L D=7$ samples from the La Democracia debris avalanche; $A G=$ Agua volcano (Carr and Rose, 1987); MF = Meseta and Fuego volcanoes (Chesner and Rose, 1984). Major oxides are given in per cent and trace elements are given in parts per million.

${ }^{a} \mathrm{FeO}$ is expressed in term of $\mathrm{Fe}_{2} \mathrm{O}_{3}$.

1). The range of composition differs from that of the Escuintla debris avalanche.

Weathering to depths of $6 \mathrm{~m}$ or more suggests an age of tens of thousands of years (Mohr et al., 1973; Birkeland, 1984). The lack of Los Chocoyos ash on the surface of the avalanche suggests that it is younger than $85 \mathrm{ka}$. The deposit is more extensively weathered than the Escuintla debris avalanche, and therefore likely predates it.

The Fuego-Meseta-Acatenango massif is the only apparent source for the avalanche. However, the range of composition represented by clasts collected from the avalanche does not match that of either Acatenango or Meseta. Although the hummocks contain lithologies similar in chemical range to those of Fucgo, it appears that the La Democracia avalanche is much older than Fuego volcano. Thus, the volcano that collapsed to form the La Democracia debris avalanche is apparently eroded or buried by more recent volcanic rocks.

\subsection{Tecuamburro volcano}

Tecuamburro volcano is an andesitic to dacitic Holocene dome complex comprising four separate vents within the edifice-collapse scarp of an older andesitic stratovolcano called Miraflores (Duffield et al., 1989, 1991). Three debris-avalanche deposits are found near Tecuamburro volcano (Fig. 4). The oldest of these came from the Miraflores scarp and the younger two came from a dacitic dome on the west side of Tecuamburro. The age of the oldest debris-avalanche deposit is constrained by the approximate $100 \mathrm{ka}$ age of Miraflores volcano, and a radiocarbon age of $38,300 \pm 1000$ $y r$ of the pyroclastic flows overlying it (Duffield et al., 1991).

The Miraflores debris-avalanche deposit covers an area of about $10 \mathrm{~km}^{2}$ east of Tecuamburro (Fig. 4), but has not been traced further down the Río Los Esclavos valley. In the large poorly vegetated debris fan downstream that extends about $15 \mathrm{~km}$ out onto the coastal plain we looked for but did not find definitive evidence of a debris-avalanche deposit. The fan is underlain by pebble- to cobble-sized alluvium and sand and its continuing aggradation has impounded three large lakes. Alluvial cobbles found at distances of $10 \mathrm{~km}$ or more away from the mountain front could have been derived from local deposits of debris flows or debris avalanches. Several hummocks at Los Cerritos are covered with these alluvial cobbles but the hummock interiors are not exposed so their origin is unknown.

The Miraflores scarp, although partly buried by younger rock of Tecuamburro volcano, is at least $4 \mathrm{~km}$ wide and $6 \mathrm{~km}$ long and has walls $100-300 \mathrm{~m}$ high. A conservative estimate of the volume of rock missing from the scarp is $4 \mathrm{~km}^{3}$. If all of the missing rock was incorporated into a debris avalanche, then it is very likely that such a large avalanche would have traveled many kilometers out onto the Pacific coastal plain. Although we did not find features that are diagnostic of a debris-avalanche deposit on the large unvegetated fan because it is now extensively covered by young fluvial deposits, it is, nevertheless, possible that a debris-avalanche deposit underlies parts of it.

The two younger debris avalanches traveled $3-4 \mathrm{~km}$ from their sources, and their combined deposits now underlie $7 \mathrm{~km}^{2}$ north of Tecuamburro volcano (Fig. 4). The younger deposit overlies a tuff ring containing a soil that is radiocarbon dated at $2910 \pm 70 \mathrm{yr}$; the 


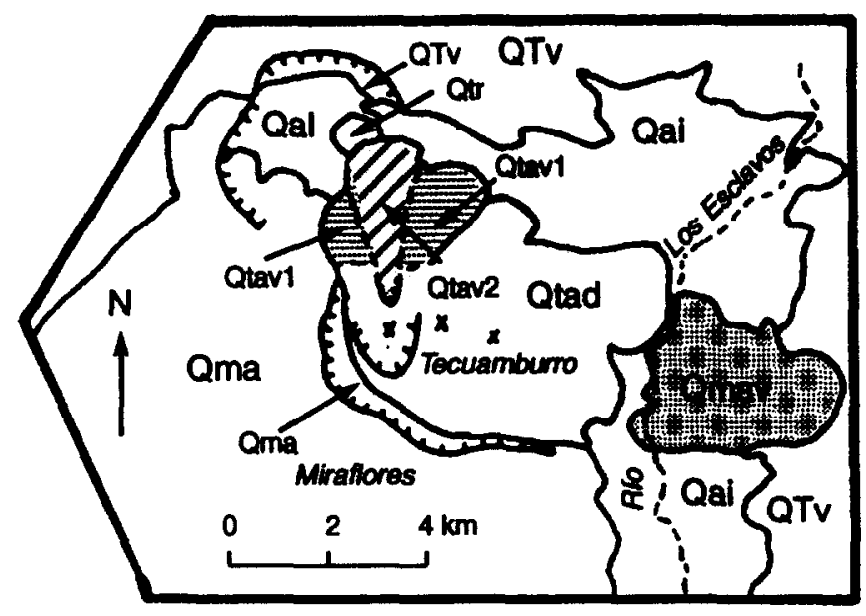

Fig. 4. General geology of Tecuamburro volcano and vicinity, adapted from Duffield et al. (1991). Units from oldest to youngest: $Q T v=$ undifferentiated volcanic rock of Quaternary and Tertiary age; $Q m a=$ andesite from the circa $100 \mathrm{ka}$ Miraflores stratovolcano; $Q m a v=$ the Miraflores debris-avalanche deposit; $Q a i=$ andesitic pyroclastic flows of $38 \mathrm{ka}$; $Q \mathrm{tad}=$ dacite and andesite of the Tecuamburro dome complex; Qtanl = a Holocene debris-avalanche deposit from Tecuamburro; $Q t r=a$ tuff-ring deposit; $Q t a w 2=$ another debris-avalanche deposit from Tecuamburro; $Q a l=$ alluvium.

older deposit is not well constrained in age but is apparently Holocene (Duffield et al., 1991).

\subsection{Cerro Quemado volcano}

Cerro Quemado (Figs. 1, 5 and 6) is an exogenous dome complex of Holocene age, having borderline andesite to dacite composition, and is located in the back-arc Almolonga volcanic field $5 \mathrm{~km}$ west of Quezaltenango, Guatemala's second largest city (Vallance et al., 1989; Conway et al., 1992). The central dome has an avalanche scar $1 \mathrm{~km}$ by $1.5 \mathrm{~km}$ and up to $90 \mathrm{~m}$ deep. The dome complex, which has an area of $12 \mathrm{~km}^{2}$ and a volume of nearly $2 \mathrm{~km}^{3}$, was last active from January to July 1818 (Johns, 1975; Conway et al., 1992). The 1818 eruption was typical of past eruptions producing a blocky lava flow about $2.5 \mathrm{~km}$ long, 120 $\mathrm{m}$ thick and $1.8 \mathrm{~km}^{2}$ in extent, a plug dome and tephra of limited areal extent (Gall, 1966).

About 1200 radiocarbon years B.P., Cerro Quemado erupted explosively to form a debris avalanche, a laterally directed pyroclastic blast and pyroclastic flows. The sequence of events during this episode of volcanism was: shallow intrusion or extrusion and cooling of magma; disruption and failure of the edifice; laterally directed explosions due to disruption and fragmentation of hot dome rock; pyroclastic flows derived from secondary flow of hot lateral blast deposits down steep slopes; and subsequent rain-induced lahars. The abundance of massive prismatically jointed dome rock and vitreous charcoal in the pyroclastic blast and flow deposits suggests that the source rock was hot. The lack of vesicularity in juvenile rock suggests that it was almost completely degassed before the collapse event. This in turn suggests that the magma had cooled at very shallow depths before the eruption. An alternate hypothesis consistent with these observations is that the blast was formed of hot rock that had already been emplaced at the surface as a dome.

The age of the edifice collapse is constrained by five radiocarbon ages from charcoal contained in the genetically related pyroclastic blast and flow deposits. The radiocarbon ages range from 1440 to $980 \mathrm{yr}$ B.P. and cluster around 1200 yr B.P. (Conway et al., 1992). The 1200-yr-B.P. age corrected for temporal variations in atmospheric $\mathrm{CO}_{2}$ is about 1150 yr B.P. (Stuiver and Pearson, 1986).

The debris avalanche underlies $13 \mathrm{~km}^{3}$ of the Llano del Pinal valley, averages about $10 \mathrm{~m}$ thick, and thus has a volume of about $0.13 \mathrm{~km}^{3}$-about the same as that missing from the summit dome of Cerro Quemado. The surface of the deposit is characterized by numcrous hummocks, and a few closed depressions. The hummocks are typically oval in plan view and up to $15 \mathrm{~m}$ high, but several near the base of the avalanche scarp form ridges up to $1000 \mathrm{~m}$ long and $50-100 \mathrm{~m}$ wide that 


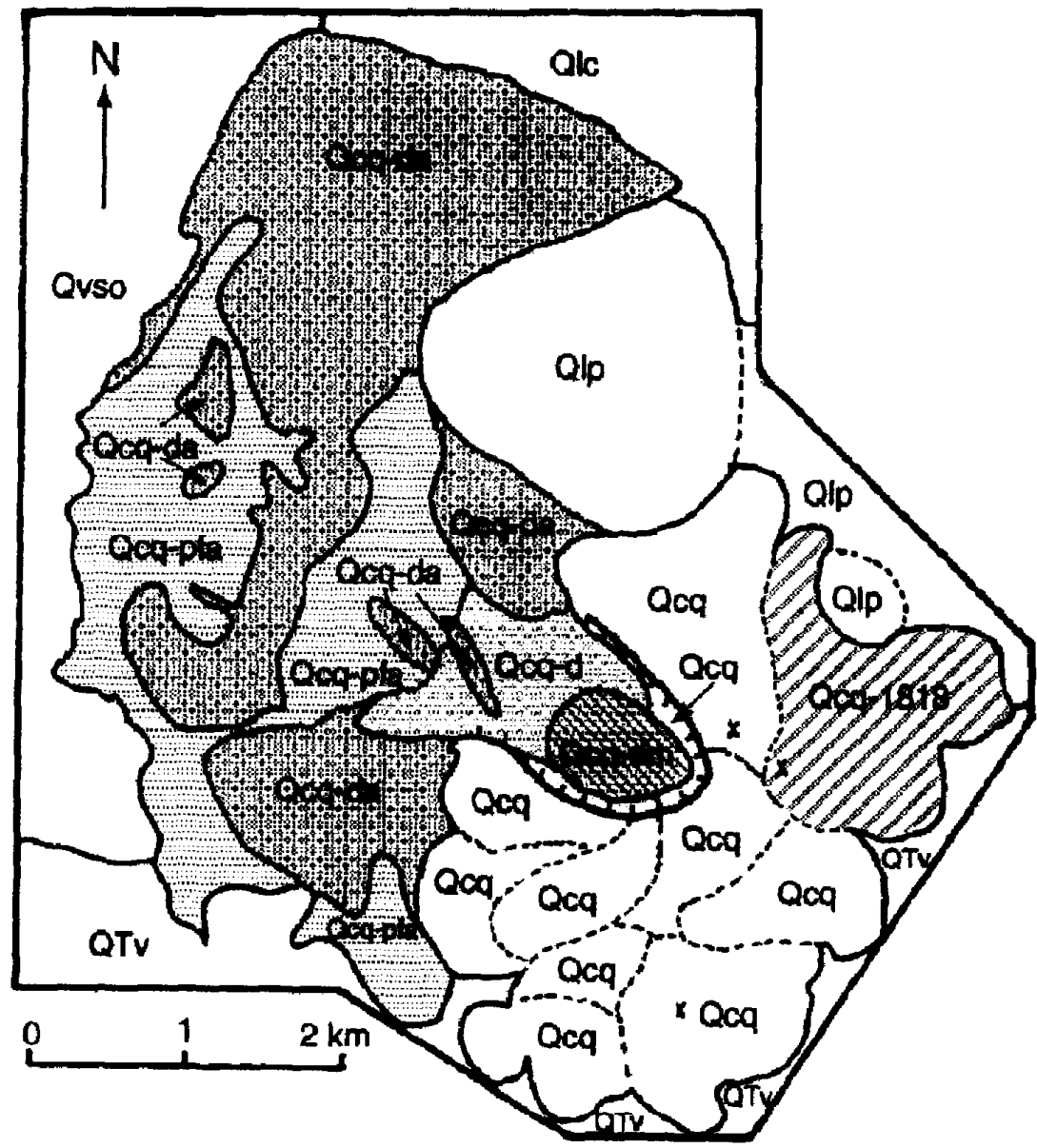

Fig. 5. Geolugic Inilp of Cerro Quemalo and vicinily, bediuck geology is modified from Johns (1975). Units from oldest to youngest: $Q T V=$ undifferentiated volcanic rock of Tertiary and Quaternary age; Qlso=andesite and basaltic andesite of Siete Orejas stratovolcano; $Q k=$ myolitic pyroclastic-flow deposits of the $84 \mathrm{ka} L u s$ Chocoyos ignimbrite; $Q l p=$ rhyolitic to dacitic lavas and domes of La Pedrera; $Q c q=$ andesitic to dacitic lavas and domes of Cerro Quemado, units colored various shades of gray are the products of the 1200 yr B.P. eruption of Cerro Quemado ( $Q r q-d t=$ debris -avalanche deposit: $Q c q$-pfa $=$ secondary pyroclastic-flow deposit. in places overlain by lahar deposits and alluvium; $Q c q-d m=$ dome; $Q c q \cdot d=$ debris shed during and after dome growth); $Q c q-1818=$ lava flow of 1818 A.D. (denoted with a diagonal striped pattern?.

are oriented transversely or longitudinally to the axis of the scarp. Numerous hummock deposits exposed by quarrying are composed of fragmental, massive, poorly sorted mixtures of pebble-, cobble- and boulder-size rocks up to $4 \mathrm{~m}$ in diameter in a sandy matrix. Clasts are more than $95 \%$ of Cerro Quemado origin but also include diatomite clasts from a dry lake bed, measuring up to $2 \mathrm{~m}$, and ripped-up soil.

The pyroclastic blast deposit covers about $40 \mathrm{~km}^{2}$ in a discontinuous sheet extending west from the vent and more than $500 \mathrm{~m}$ up onto the opposing slopes of Siete Orejas (Fig. 6). The distribution of the deposit sub- tends an arc of $110^{\circ}$, is symmetrical about an axis of $\mathrm{N} 70^{\circ} \mathrm{W}$ that also matches that of the center of the avalanche scarp, and is thus consistent with a source in the scarp area (Fig. 6). In the Llano del Pinal valley, the laterally directed blast deposit overlies the debris-avalanche deposit (Fig. 6). The sharp to transitional contact, incorporation of avalanche material, and the lack of a weathering profile is consistent with contemporaneous deposition of the blast and avalanche. The deposit is typically fines deficient and contains carbonized twigs and stems and ripped-up soil, in addition to rocks of Cerro Quemado. In the valley and on opposing 
A

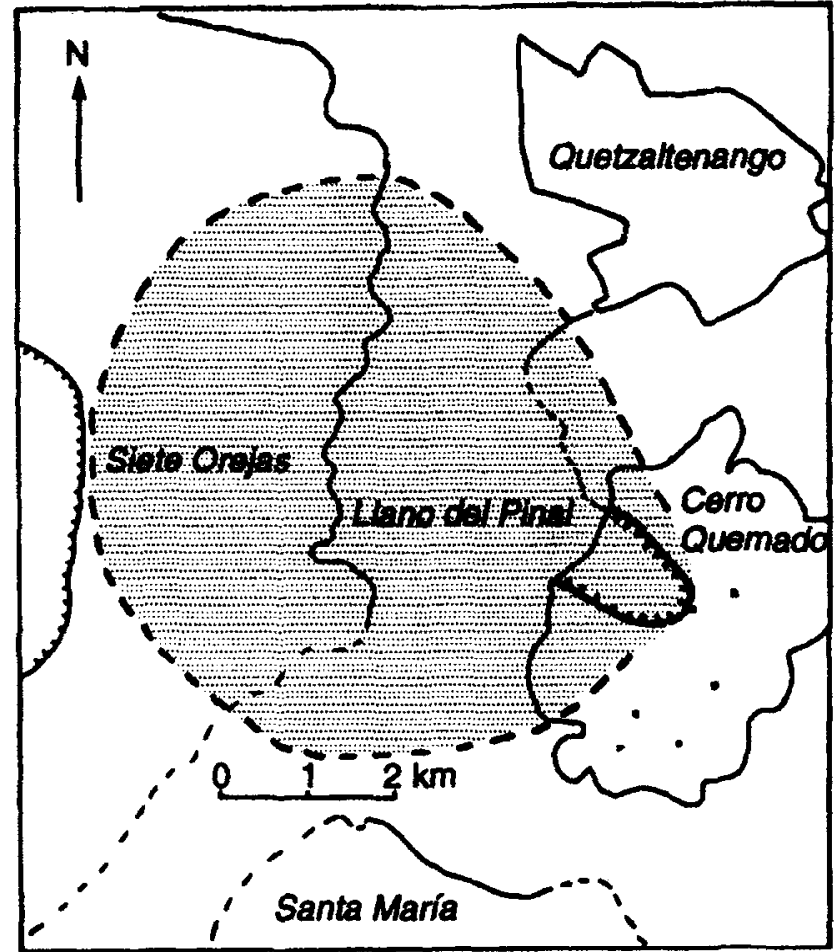

B Schematic Cross Section

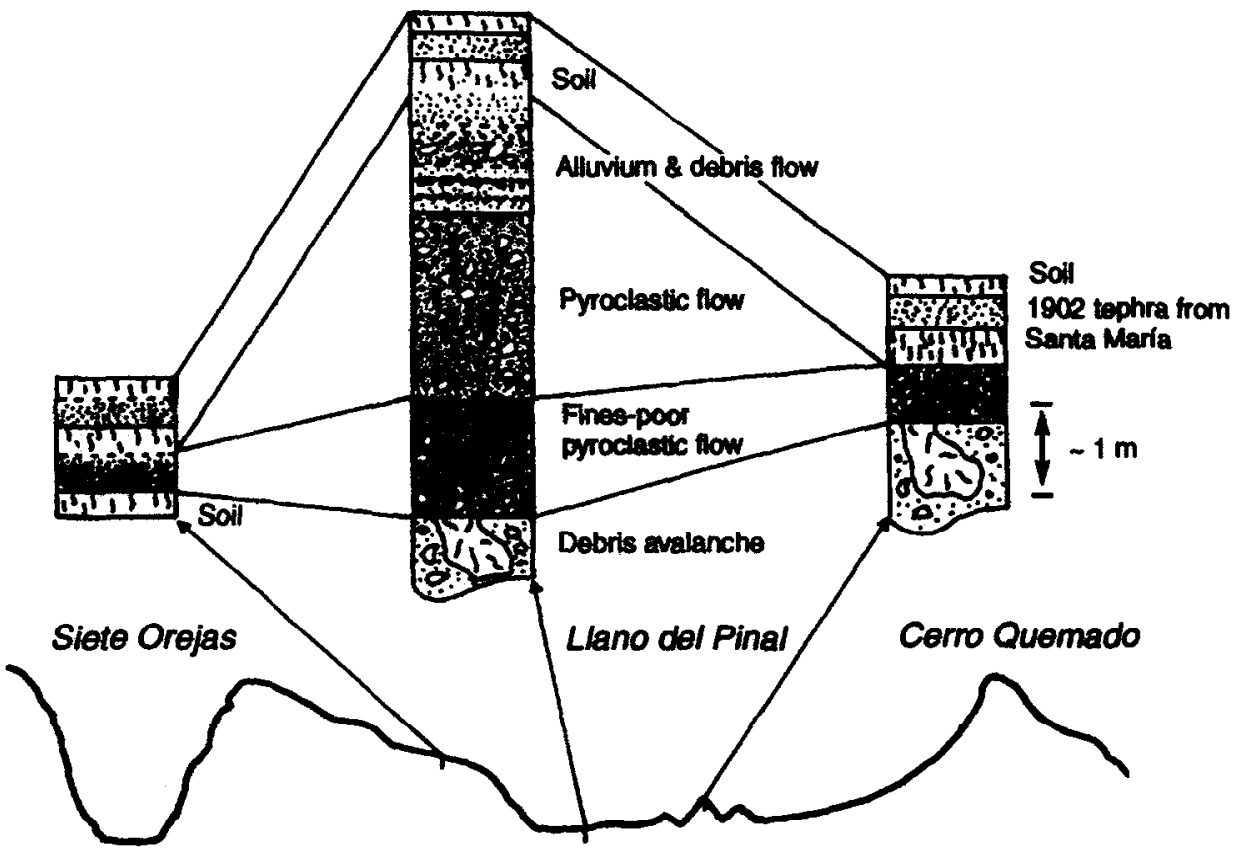

Fig. 6. Map (A) and schematic cross section (B) showing the distribution and relationship with other units of the laterally directed blast deposit of 1200 yr B.P. in Llano del Pinal and on the slopes of Siete Orejas. The profile is not to scale. 
Tuble 2

Characuerstics of Guatemalan volcanoses which could relate to the probability or nature of edifice collapse

\begin{tabular}{|c|c|c|c|c|c|c|c|c|c|c|}
\hline Votuanou & $\begin{array}{l}\text { Elcu, } \\
(\mathrm{m})\end{array}$ & $\begin{array}{l}\text { L.ariath } \\
\left(\mathrm{SiO}_{2}\right) \mathrm{F!}\end{array}$ & Domes & $\begin{array}{l}\text { Collapse: } \\
\text { scars }\end{array}$ & $\begin{array}{l}\text { Structural } \\
\text { comments }\end{array}$ & $\begin{array}{l}\text { Hydrothermal } \\
\text { alteration }\end{array}$ & $\begin{array}{l}\text { Regional } \\
\text { slope } \\
\text { (up/down) }\end{array}$ & $\begin{array}{l}\text { Pairing } \\
\text { with }\end{array}$ & $\begin{array}{l}\text { Preferred } \\
\text { failure } \\
\text { direction" }\end{array}$ & Miscellaneous \\
\hline Tacaná & $4(x) 3$ & $55-601$ & Many & $\begin{array}{l}\text { Several } \\
\text { smitll }\end{array}$ & $\begin{array}{l}\text { Elongate, } \\
\mathrm{NE} \text {-SW }\end{array}$ & $\begin{array}{l}\text { Small volume, } \\
\text { moderate }\end{array}$ & $\mathrm{NE} / \mathrm{SW}$ & None & SW 1.3 & $\begin{array}{l}\text { Domes and } \\
\text { pyroclastic } \\
\text { rocks are } \\
\text { commoni }\end{array}$ \\
\hline Tajumbilco & +2211 & $52-69$ & Severit & & Satellite dome & $\begin{array}{l}\text { Moderate in } \\
\text { places. } \\
\text { unknown } \\
\text { volume }\end{array}$ & $\mathrm{NE} / \mathrm{SW}$ & None & SW 1,3 & $\begin{array}{l}\text { Lava flows and } \\
\text { flank domes } \\
\text { ncar summit }\end{array}$ \\
\hline Chicahal & $-2 y(x)$ & 53.58 & None & $\begin{array}{l}\text { ()ic } \\
\text { possible } \\
\text { surrounds } \\
\text { cont }\end{array}$ & $\begin{array}{l}\text { Caldera ("). } \\
\text { hreached } S W\end{array}$ & Litule evident & $\mathrm{NE} / \mathrm{SW}$ & $\begin{array}{l}\text { Siete } \\
\text { Orejas }\end{array}$ & SW 1.3 & - \\
\hline Sick Orejow & 3370 & $52 \cdots 72$ & Ne:al rim & None: & $\begin{array}{l}\text { Caldera (?). } \\
\text { hnached S }\end{array}$ & $\begin{array}{l}\text { Moderate in } \\
\text { places } \\
\text { willin crater }\end{array}$ & $\mathrm{N} / \mathrm{S}$ & Chicabal & - & Not active \\
\hline $\begin{array}{l}\text { Cerro } \\
\text { Quemado }\end{array}$ & 3197 & $50-6 x$ & All & One & $\begin{array}{l}\text { Exugenous } \\
\text { dome } \\
\text { complex, lavis } \\
\text { flows }\end{array}$ & Little evident & $S W / N E$ & $\begin{array}{l}\text { Santa } \\
\text { Marfa }\end{array}$ & $\begin{array}{l}\text { NE L : W } \\
\text { or E } 3\end{array}$ & $\begin{array}{l}\text { Dome collapse } \\
\text { and lateral } \\
\text { blast. } 1200 \text { yr } \\
\text { B.P. }\end{array}$ \\
\hline Santa Maríd & .3772 & $51-56$ & Summ & None & $\begin{array}{l}\text { Very steep S } \\
\text { llank } \\
\text { due to } 1 \text { wor } \\
\text { crater }\end{array}$ & Listte evident & NNE/SSW & $\begin{array}{l}\text { Cerro } \\
\text { Quemado }\end{array}$ & SW 1,3 & - \\
\hline Santiaguito & $-25(n)$ & $57 \ldots 6$ & All & $\begin{array}{l}\text { Several } \\
\text { small }\end{array}$ & Elongate, $E-W$ & $\begin{array}{l}\text { Minor near } \\
\text { Caliente vent }\end{array}$ & NNE/SSW & - & $S 1,3$ & $\begin{array}{l}\text { Possible } \\
\text { collapse of hot } \\
\text { rock during } \\
1929 \text { eruption }\end{array}$ \\
\hline Zuñil & 3353 & 014.75 & $\begin{array}{l}\text { on } \\
\text { nianks } \\
\text { along } \\
\text { timn }\end{array}$ & & $\begin{array}{l}\text { Caldera i? } \\
\text { breached } \mathrm{S}\end{array}$ & $\begin{array}{l}\text { Moderate in } \\
\text { places. } \\
\text { unknown } \\
\text { volume }\end{array}$ & NNE/SSW & Pecul & - & $\begin{array}{l}\text { "Old" center. } \\
\text { not now active }\end{array}$ \\
\hline $\begin{array}{l}\text { Pecul } \\
\text { (Sunt) } \\
\text { Tomás) }\end{array}$ & 35115 & $\because 2-?$ & $\begin{array}{l}\text { ()n } \\
\text { 4illnmil }\end{array}$ & & $\begin{array}{l}\text { Symmetrical } \\
\text { cone } \\
\text { within A titlár } \\
\text { caldera }\end{array}$ & - & NNE/SSW & Zuñil & $\mathrm{S}: 1,2$ & $\ldots$ \\
\hline San Pedru & 2905 & $\therefore 1 \ldots 60$ & $\begin{array}{l}\text { Summil } \\
\text { and } \\
\text { several } \\
\text { tlank }\end{array}$ & & & Little evident & $\begin{array}{l}S / N \\
\text { into caldera }\end{array}$ & None & NE 1 & $\begin{array}{l}\text { An avalanche } \\
\text { entering Lake } \\
\text { Atitlán could } \\
\text { cause huge } \\
\text { waves }\end{array}$ \\
\hline Tolimán & 3158 & $40-64$ & Miny & $\begin{array}{l}\text { Several } \\
\text { smill }\end{array}$ & $\begin{array}{l}\mathrm{N}-\mathrm{S} \text { vent } \\
\text { alignment }\end{array}$ & Little evident & $S / N$ & Atitlán & $\mathrm{N} 1,2$ & $\begin{array}{l}\text { An avalanche } \\
\text { entering Lake } \\
\text { Atitlán could } \\
\text { cause huge } \\
\text { waves }\end{array}$ \\
\hline Alitlăn & 3.537 & $49-56$ & Nonce & Simall & $\begin{array}{l}\mathrm{N}-\mathrm{S} \text { vent } \\
\text { alignment }\end{array}$ & Little evident & $N / S$ & Tolimán & S 1.2 & - \\
\hline Fucgu & 3763 & 47.55 & Nolse & $\begin{array}{l}\text { Meseta } \\
\text { scarp }\end{array}$ & $\begin{array}{l}N-S \text { vent } \\
\text { alignment }\end{array}$ & $\begin{array}{l}\text { Minor near } \\
\text { summil crater }\end{array}$ & $N / S$ & Acatenango & $\begin{array}{l}S 1,2 ; \mathrm{SE} \\
\text { or } \mathrm{SW} 3\end{array}$ & - \\
\hline Acatenallgen & 3476 & $51-63$ & None & $\begin{array}{l}\text { Nonc } \\
\text { upparent }\end{array}$ & $\begin{array}{l}\mathrm{N}-\mathrm{S} \text { vent } \\
\text { alignment }\end{array}$ & $\begin{array}{l}\text { Small volume } \\
\text { in summit area }\end{array}$ & - & Fuego & $\begin{array}{l}\text { N2; E or } \\
W 3\end{array}$ & - \\
\hline Aggual & 37601 & +9-60) & Nune & $\begin{array}{l}\text { None } \\
\text { apparint }\end{array}$ & Symmetrical & Little evident & $N / S$ & None & S 1 & - \\
\hline Pacaya & $-2(x)$ & 4353 & $N(n):$ & $\begin{array}{l}\text { One, } \\
\text { pussibly } \\
\text { two }\end{array}$ & $\begin{array}{l}\text { Primary cone } \\
\text { is within } \\
\text { amphitheater } \\
\text { open to } S S W\end{array}$ & Litle evident & $\mathrm{N} / \mathrm{S}$ & None & $S 1,3$ & $\begin{array}{l}\text { Stratovolcano } \\
\text { possibly built } \\
\text { on weak } \\
\text { pyroclastic } \\
\text { rocks }\end{array}$ \\
\hline Tecuamburru & $-17(9)$ & 5365 & Several & Three & $\begin{array}{l}\text { Vents aligned } \\
\text { E-W } \\
\text { within crater } \\
\text { open to } E\end{array}$ & $\begin{array}{l}\text { Moderate at } \\
\text { Ixpaco }\end{array}$ & $\begin{array}{l}\text { W/E, NW/ } \\
\text { SE }\end{array}$ & None & $\begin{array}{l}\text { E } 1,3 ; N \\
\text { or } S 3\end{array}$ & $\begin{array}{l}\text { Dome complex } \\
\text { within } \\
\text { an avalanche } \\
\text { searp }\end{array}$ \\
\hline
\end{tabular}

- indiciatc no dialid.

"The prelerred failure directions given are: I = duc w) region:t slope; 2 = due to the paited volcano effect; $3=$ due to structural factors. Editice collapses are complicated phenomena with multiple

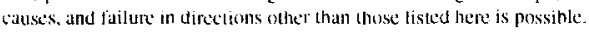


hillsides, the blast deposit is thin or absent on stoss sides of objects like hummocks or on ridges and thick (up to $2 \mathrm{~m}$ ) on the lee sides of hummocks or in depressions. It is normally graded near its top, especially on hillsides further from its source. On hillsides above Llano del Pinal, the deposit generally becomes finer grained away from source, but nevertheless contains sparse coarser-grained bombs. In its distribution and texture, the blast deposit strongly resembles the deposit of the Sugar Bowl lateral blast at Mount St. Helens (Crandell and Hoblitt, 1986).

A fines-rich pyroclastic flow deposit that overlies the lateral blast deposit in the Llano del Pinal valley has a distribution (Fig. 5) suggesting a source other than the scarp area. If the pyroclastic flow emanated from the crater, it should have inundated the central Llano del Pinal and then moved northward toward Quezaltenango, but the deposits are principally found up valley to the south and also at the base of Siete Orejas (Fig. 5 ), and this distribution implies a different origin. We suggest that subsequent gravitational flow of the hot, lateral-blast debris from the surrounding steep hill slopes caused the fines-rich pyroclastic flow-an origin similar to that of the valley-ponded pyroclastic flows associated with the 1980 lateral blast at Mount St. Helens (Hoblitt et al., 1981).

\subsection{Possible collapse scars and related deposits}

Sevcral possible breached collapse scarps include those at the volcanoes, Zuñil, Siete Orejas and Chicabal, as well as an unnamed volcano $12 \mathrm{~km}$ east of $\mathrm{El}$ Tumbador (several others are listed in Table 2). Zuñil volcano appears to have a breach narrower than its crater, suggesting an erosionally breached caldera. Debris-avalanche deposits were not identified downstream, south from the crater of Zunil, and a debris avalanche, if any, probably predates the Los Chocoyos ignimbrite. A $0.001-\mathrm{km}^{3}$ debris avalanche killed 33 people in 1991 to the west of the volcano at the Zuñil geothermal field (Voight, 1992). It is $200-300 \mathrm{~m}$ wide and moved about $1 \mathrm{~km}$ down slope.

The Siete Orejas crater is nearly $3.5 \mathrm{~km}$ wide and narrows slightly at its breach. Avalanche deposits were not identified along Río Oscosito, the river that drains Sicte Orejas. Scveral hummocks observed in the flood plain between Río Oscosito and Río Samalá were used by prehistoric men, but their origin is unknown. A diamicton up to $9 \mathrm{~m}$ thick, having some characteristics of a debris-avalanche deposit, crops out between Río Oscosito and Río Nil to the west. The diamicton is characterized by small breccia clasts and 1-m-scale color variations, but bears no clast, larger than $2 \mathrm{~m}$. The diamicton is highly indurated and typically has about $4 \mathrm{~m}$ of lateritic soil developed on it. The genesis of the diamicton is unknown.

Chicabal volcano is formed in a 4-km-wide, openended scarp of unknown origin and forms the apex of a fan which is incised as much as $100 \mathrm{~m}$ by several small rivers. Exposures of the fan along the Pan-American highway show up to $8 \mathrm{~m}$ of red lateritic soil formed on a diamicton containing pebbles, cobbles, boulders and blocks. The soil contains a white ash layer that could be the Los Chocoyos ash. Extensive weathering prevents identification of the origin of the deposit. The fan causes Río Naranjo to detour $30 \mathrm{~km}$ west before flowing south to the Pacific Ocean.

An unnamed volcano $12 \mathrm{~km}$ east of El Tumbador has an amphitheater open to the west with a possible dome within it. The fan leading up to the volcano is incised $100-200 \mathrm{~m}$ by several rivers. Outcrops expose a diamicton having more than $10 \mathrm{~m}$ of soil developed on it. The diamicton may be an avalanche deposit, but it is much too deeply weathered for a definitive evaluation of its origin.

\section{Hazards from edifice collapse events in Guatemala}

Although relatively rare, about four per century worldwide (Siebert et al., 1987), edifice collapses are extremely dangerous because associated debris avalanches, lateral blasts and lahars can move rapidly and totally destroy everything in their paths. One cannot predict when or where a collapse event might next occur in Guatemala, but features of the Guatemalan volcanic chain suggest that the probability of collapse is greater in some areas than others.

A slope failure occurs when driving forces acting along a potential shear surface exceed the forces resisting failure (a more complete discussion of this topic may be found in Voight, 1992). Forces that favor failure at a volcano include gravity, earthquakes and explosions. The forces resisting failure depend on the strength of the rock within the volcano. The probability 

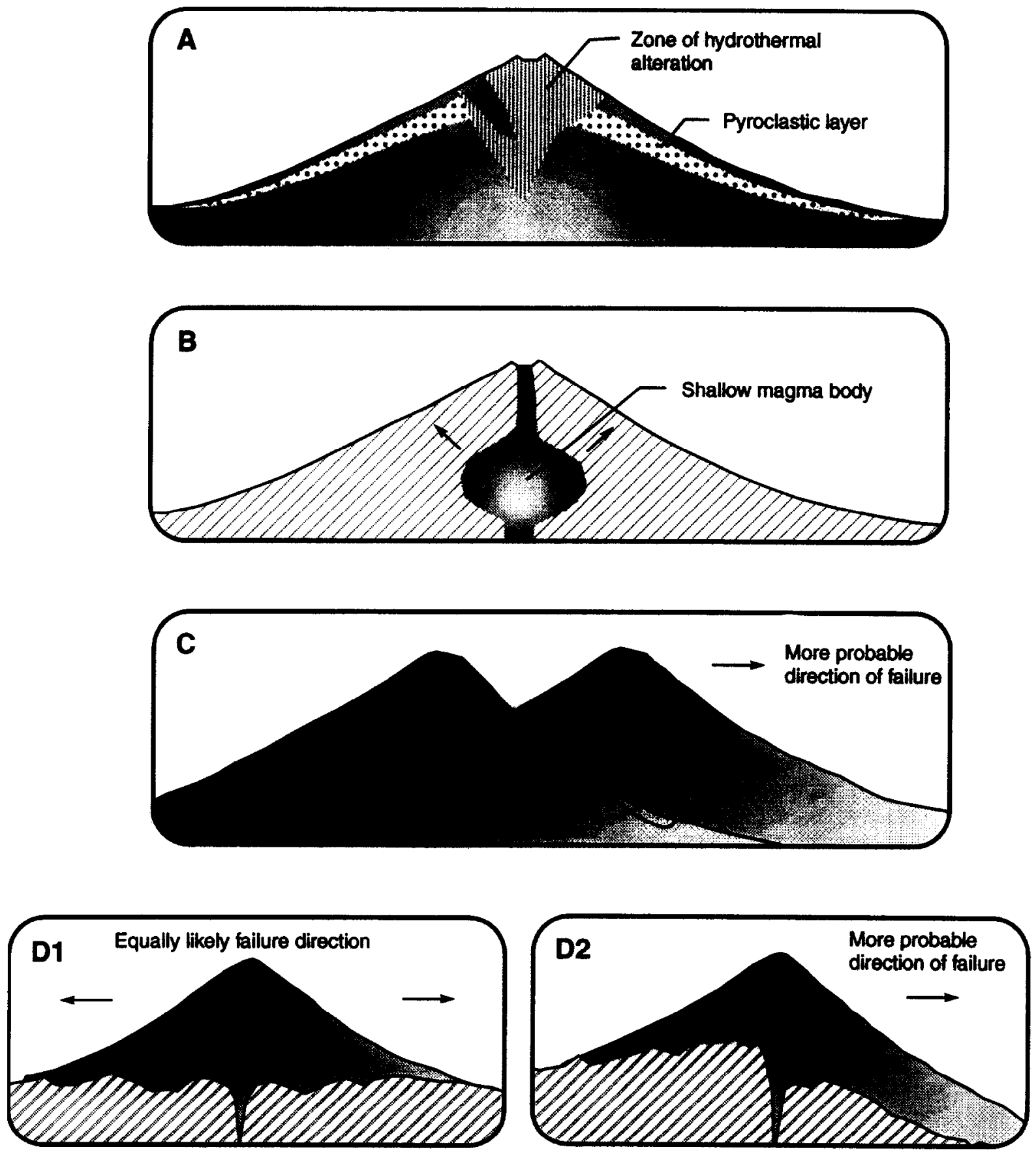

Fig. 7. Conditions which could influence the probability and direction of edifice-collapse events. (A) zones of hydrothermal alteration and less competent clastic beds may form zones of weakness within the edifice; further. less competent layers may form natural planes of weakness. (B) the intrusion of magma to a shallow depth may cause deformation which would weaken the edifice. (C) possible zones of weakness may exist along the boundary between paired volcanoes. Because the youngest of four such Guatemalan volcano pairs is always to the south and the possible zones of weakness dip to the south, the preferred failure direction is also to the south. (D) the orientation of bedrock underlying a volcano may influence the direction of possible future edifice collapse. 
for slope failure is increased by the presence of weak beds such as pyroclastic beds and zones of hydrothermal alteration (Fig. 7A).

Most of the Guatemalan volcanoes listed in Table 2 have pyroclastic beds, and several have zones of hydrothermal alteration. For example, a thick sequence of basaltic lava flows caps a pyroclastic core at ancestral Pacaya volcano; this condition, which contributed to collapse at volcanoes such as Bandai-san and which probably contributed to ancestral Pacaya's collapse, could also weaken the present Pacaya cone. Acatenango and Tajumulco may be more strongly affected by hydrothermal processes than the other Guatemalan volcanoes (Table 2). Disruption of the structure of a volcano by the intrusion of a shallow magma body could increase the probability of an edifice collapse (Fig. 7B). An avalanche in the presence of a shallow magma body could unload the magma causing explosive decompression leading to a laterally directed blast like that during the 1980 eruption of Mount St. Helens (Lipman and Mullineaux, 1981).

Four sets of paired volcanoes exist in Guatemala (Table 2), and Halsor and Rose (1988) note that the younger of each set is invariably to the south toward the subduction zone. The flank of an older volcano like Acatenango could have an internal plane of weakness for a younger overlapping volcano like Fuego (Fig. $7 \mathrm{C}$ ). Moreover, because of the general $\mathrm{N}-\mathrm{S}$-directed regional slope, a volcano like Fuego is more likely to collapse away from its pair (Fig. 7C).

In Guatemala the general slope between the highlands and the coastal plain is north to south and collapse is more likely to occur in the direction of regional slope (Fig. 7D). Exceptions occur, for both San Pedro and Tolimán are situated on regional $\mathrm{S}-\mathrm{N}$-directed slopes. Possible collapses occurring at these two volcanoes could flow north into Lake Atitlán, and could cause huge waves in the lake. During historic times, waves from avalanches moving into water have caused more fatalities worldwide than the avalanches themselves (Siebert et al., 1987; Kienle et al., 1987). An avalanche flowing suddenly into Lake Atitlán could cause a wave that could inundate property up to several tens of meters above normal lake level. The exact amount of run-up depends on the size, shape and velocity of the avalanche as well as the distance traveled and local conditions at any section of shoreline (Slingerland and Voight, 1979).
Structural factors may weaken volcanoes and also predispose them to fail in a particular direction. Santa María may be more apt to fail southward because of its eccentric steep-walled 1902 crater.

In the absence of other factors a symmetrical cone is equally likely to fail in any direction, whereas coalescing chains of cones such as dome complexes are more likely to fail in a direction normal to the trend of the chain. In Guatemala, dome complexes at Santiaguito, Cerro Quemado and Tecuamburro all have formed such strings of coalescing edifices, and thus have preferred failure directions that may oppose regional slope (Table 2).

Small- to moderate-size avalanches seem to be common at domes and dome complexes. The 1929 pyroclastic event at Santiaguito may have had its origin as a slope failure (Sapper and Termer, 1930). If so, then each of the dome complexes noted above has experienced some form of edifice collapse in Holocene times.

Some populated areas in Guatemala could be affected by major debris avalanches from multiple sources. For example, debris avalanches originating from Agua, Fuego, Acatenango, or Pacaya volcanoes could affect the Escuintla area, a major commercial area with a population in excess of 100,000 , because major drainages heading on each of these volcanoes funnel into the Escuintla area (Fig. 3). Such areas are at greater risk from volcanic debris avalanches than other areas.

The probable travel distance $(L)$ of debris avalanches can be estimated by considering the vertical drop $(H)$ and setting the ratio $(H / L)$ equal to a constant known as the coefficient of friction (Pariseau and Voight, 1979; Schuster and Crandell, 1984; Crandell, 1989). Siebert et al. (1987, 1995 - this volume) have examined about 80 examples, and found that $H / L$ varies between 0.09 and 0.18 and averages 0.13 for debris avalanches with volumes between 0.1 and $1.0 \mathrm{~km}^{3}$. For avalanches greater in volume than $1 \mathrm{~km}^{3}, H / L$ varies between 0.04 and 0.13 .

Assuming that pre-avalanche Pacaya was approximately $200 \mathrm{~m}$ higher than it is now, $H / L$ is about 0.1 for the Pacaya debris avalanche. Assuming a source at Meseta or Fuego, and a volcano having about the same height as Fuego, the Escuintla and La Democracia debris avalanches have $H / L$ of 0.074 and 0.079 . Volcanoes of Guatemala have a maximum observed height of $4220 \mathrm{~m}$ above sea level, but most do not exceed 3800 
$\mathrm{m}$ (Table 2). Using $3800 \mathrm{~m}$ as a maximum value for $H$ and assuming 0.075 as a minimum value for $H / L$, travel distances for future Guatemalan debris avalanches should not exceed that of the Escuintla debris avalanche-about $50 \mathrm{~km}$. Future debris avalanches having volumes less than $1 \mathrm{~km}^{3}$ probably will not have travel distances greater than that of the Pacaya avalanche-about $25 \mathrm{~km}$. Future lateral blast events could travel from about $10 \mathrm{~km}$ to a maximum of about $35 \mathrm{~km}$ from source (Crandell and Hoblitt, 1986).

Collapse events should be considered possible at all steep volcanoes. At least seven such events have occurred in Guatemala in the past 100,000 years, and four have occurred during Holocene times. Although rare, edifice collapse events represent devastating hazards, and volcanic observers should be sensitive to precursors.

Volcanic collapse events accompanied by magmatic eruptions like those of Mount St. Helens and Bezymianny will probably be preceded by large-scale deformation and intense seismicity that should indicate the probable direction of slope failure and potential lateral blast. Events like those at Bandai-san and Unzen could occur with less premonitory activity (Siebert et al., 1987). If precursors suggest an edifice collapse event at a Guatemalan volcano, evacuation is the only effective mitigative measure.

\section{Acknowledgements}

This study is a result of a cooperative effort among the United States Geological Survey Volcano Crisis Assistance Team, Michigan Technological University and Instituto Nacional de Sismología, Vulcanología, Meteorología e Hidrología, Guatemala (INSIVUMEH). Funding was provided by the Office of Foreign Disaster Assistance of USAID, Washington DC. Lee Siebert was supported by a grant from the Smithsonian Institution. INSIVUMEH provided logistical support in Guatemala, and we especially thank Ingeniero Estuardo Velásquez Váquez, Director General, and Señor Eddy Hardie Sanchez-Bennet, Subdirector. We also thank Licenciado Enrique Molina, Jefe of Sección Sismología and Otoniel Matías. Norm MacLeod and Barry Voight reviewed the manuscript and made numerous helpful suggestions. Last, we would like to acknowledge Harry Glicken, a friend and colleague, whose enthusiasm about volcanology and, in particular, about debris avalanches, influenced all of his colleagues.

\section{References}

Banks, N.G., 1986. Preliminary evaluation of volcanic hazards of Pacaya Volcano, Guatemala. 8 pp. (unpubl.).

Bartintzeff, J. and Deniel, C., 1992. Magmatic evolution of Pacaya and Cerro Chiquito volcanological complex, Guatemala. Bull. Volcanol., 54: 267-283.

Birkeland, P.W., 1984. Soils and Geomorphology. Oxford Univ. Press, New York, NY, 372 pp.

Bonis, S. and Salazar, O., 1973. The 1971 and 1973 eruptions of Volcano Fuego, Guatemala, and some socio-economic considerations for the volcanologist. Bull. Volcanol., 37: 394-400.

Carr, M.J. and Rose Jr., W.I., 1987. CENTAM-a data base of Central American volcanic rocks. J. Volcanol. Geotherm. Res., 33: 239-240.

Chesner, C.A. and Rose Jr., W.I., 1984. Geochemistry and evolution of the Fuego volcanic complex, Guatemala. J. Volcanol. Geotherm. Res., 21: $25-41$.

Conway, F.M., Vallance, J.W., Rose Jr., W.I., Johns, G.W. and Paniagua, S., 1992. Cerro Quemado, Guatemala: the volcanic history and hazards of an exogenous dome complex. J. Volcanol. Geotherm. Res., 52: 303-323.

Conway, F.M., Diehl, J.F. and Matías, O., 1992. Paleomagnetic constraints on eruption patterns at the Pacaya composite volcano, Guatemala. Bull. Volcanol., 55: 25-32.

Crandell, D.R., 1971. Postglacial lahars from Mount Rainier volcano, Washington. U.S. Geol. Surv., Prof. Pap. 677, 75 pp.

Crandell, D.R., 1989. Gigantic debris avalanche of Pleistocene age from ancestral Mount Shasta volcano, California, and debrisavalanche hazard zonation. U.S. Geol. Surv., Bull. 1861, 32 pp.

Crandell, D.R. and Hoblitt. R.P., 1986. Lateral blasts at Mount St. Helens and hazard zonation. Bull. Volcanol., 48: 27-37.

Davies, D.K., Querry, M.W. and Bonis, S.B., 1978. Glowing avalanches from the 1974 eruption of the volcano, Fuego, Guatemala. Geol. Soc. Am. Bull., 89: 369-384.

Duffield, W.A., Heiken, G.H., Wohletz, K.H., Maassen, L.W., Dengo, G. and McKee, E.H., 1989. Geology and geothermal potential of the Tecuamburro volcano area of Guatemala. Geotherm. Res. Counc. Trans., 13: 125-131.

Duffield, W.A., Heiken, G.H., Wohletz, K.H., Maassen, L.W., Dengo, G. and Pinzon, O., 1991. Geologic map of Tecuamburro volcano and surrounding area, Guatemala. U.S. Geol. Surv., Misc. Invest. Ser., Map I-2197, scale 1:50,000.

Eggers, A.A., 1971. The geology and petrology of the Amatitlán quadrangle, Guatemala. Ph.D. Thesis, Dartmouth College, 221 pp. (unpubl.)

Eggers, A.A., 1975. Geologic map of the Amatitlán Quadrangle, Guatemala. Inst. Geogr. Nac. Guatemala, scale 1:50,000.

Eichelberger, J.C. and McGetchin, T.R., 1976. Petrogenesis of the 1973 Pacaya lavas. Guatemala. In: O. Gonzales-Ferran (Editor), 
Andean and Antarctic Volcanological Problems. Int. Assoc. Volcanol. Chem. Earth's Interior, Naples, pp. 435-449.

Gall, F., 1966. Cerro Quemado: Volcán de Quezaltenango. Soc. Geogr. Hist. Guatemala, Publ. Espec. 12.

Glicken, H., 1986. Rockslide-debris avalanche of May 18, 1980, Mount St. Helens volcano, Washington. Ph.D. Thesis, Univ. California, Santa Barbara, CA, 303 pp. (unpubl.)

Glicken. H., 1991. Sedimentary architecture of large volcanic-debris avalanches. In: R.V. Fisher and G.A. Smith (Editors), Sedimentation in Volcanic Settings. Soc. Econ. Paleontol, Mineral., Spec. Publ., 45: 99-106.

Halsor, S.P. and Rose Jr., W.I., 1988. Common characteristics of paired volcanoes in northern Central America. J. Geophys. Res., 93: 4467-4476.

Hoblitt, R.P., Miller, C.D. and Vallance, J.W., 1981. Origin and stratigraphy of the deposit produced by the May 18 directed blast. In: P.W. Lipman and D.R. Mullineaux (Editors), The 1980 Eruptions of Mount St. Helens. Washington. U.S. Geol. Surv., Prof. Pap., 1250: 401-419.

Hunter, B., 1976. Fluvial sedimentation on an active volcanic continental margin: Río Guacalate, Guatemala. M.A. Thesis, Univ. Missouri, Columbia, MO, 135 pp. (unpubl.).

Hunter, B., Querry, M., Hebbeger, J. and Tharpe, J., 1984. Geologic Map of the Escuintla Quadrangle, Guatemala. Inst. Geogr. Mil. Guatemala, scale 1:50,000.

Janda, R.J., Scott, K.M., Nolan K.M. and Martinson, H.A., 1981. Lahar movement, effects, and deposits. In: P.W. Lipman and D.R. Mullineaux (Editors), The 1980 Eruptions of Mount St. Helens, Washington. U.S. Geol. Surv., Prof. Pap., 1250: 46I478.

Johns, G.W., 1975. Geology of the Cerro Quemado volcanic dome complex, Guatemala. M.S. Thesis, Michigan Technol. Univ. Houghton. MI, 117 pp. (unpubl.)

Kieffer, S.W., 1981. Fluid dynamics of the May 18 blast at Mount St. Helens. In: P.W. Lipman and D.R. Mullineaux (Editors), The 1980 Eruptions of Mount St. Helens, Washington. U.S. Geol. Surv., Prof. Pap., 1250:379-400.

Kienle, J., Kowalik, Z. and Murty, T., 1987. Tsunamis generated by eruptions from Mount St. Augustine Volcano, Alaska. Science, 236: $1442-1447$.

Lipman, P.W. and Mullineaux, D.R., 1981. The 1980 eruptions of Mount St. Helens. U.S. Geol. Surv., Prof. Pap. 1250, 650 pp.

Mohr, E.C.J., Van Baren, F.A. and Van Schuylenborgh, J., 1973. Tropical Soils. Mouton-Ichtiar Baru-Van Hoeve, The Hague, 481 pp.

Pariseau, W.G. and Voight, B., 1979. Rockslides and avalanches: basic principles, and perspectives in the realm of civil and mining operations. In: B. Voight (Editor), Rockslides and Avalanches, 2. Elsevier, New York, NY, pp. 1-92.

Kose Jr., W.I., Anderson Jr., A.I., Woodruff, L.G. and Bonis, S.B., 1978. The October 1974 basaltic tephra from Fuego Volcano: description and history of the magma body. J. Volcanol. Geotherm. Res., 4: 3-53.

Rose Jr., W.I.. Johnson, D.J., Hahn, G.A. and Johns, G.W., 1975. Skylab photography applied to geological mapping in northwestern Central America. Proc. Natl. Aeronautics and Space Administration, Earth Resour. Surv. Symp., lb: 861-884.
Rose Jr., W.I., Pearson, T. and Bonis, S.B., 1977. Nuée ardente eruption from the foot of a dacite lava flow, Santiaguito Volcano, Guatemala. Bull. Volcanol., 40: 1-16.

Sapper, K. and Termer, F., 1930. Der Aüsbruch des Vulkans Santa María in Guatemala von 2-4 November 1929. Z. Vulkanol., 13: 79-180.

Schuster, R.L. and Crandell, D.R., 1984. Catastrophic debris avalanches from volcanoes. Proc. IV Int. Symp. on Landslide, Toronto, 1: 567-572.

Scott, K.M., Pringle, P.T. and Vallance, J.W., 1992. Sedimentology, behavior, and hazards of debris flows at Mount Rainier, Washington. U.S. Geol. Surv., Open-file Rep. 90-385, 106 pp.

Siebert, L., 1984. Large volcanic debris avalanches: characteristics of source areas, deposits, and associated eruptions. J. Volcanol. Geotherm. Res., 22: 163-197.

Siebert, L., Beget, J.E. and Glicken, H., 1995. The 1883 and lateprehistoric eruptions of Augustine volcano, Alaska. In: J. Volcanol. Geotherm. Res., 66: (this volume).

Siebert, L., Glicken, H. and Ui, T., 1987. Volcanic hazards from Bezymianny- and Bandai-type eruptions. Bull. Volcanol., 49: $435-459$.

Slingerland, R.L. and Voight, B., 1979. Occurrences, properties, and predictive models of landslide-generated water waves. In: $\mathbf{B}$. Voight (Editor), Rockslides and Avalanches, 2. Elsevier, New York, NY, pp. 317-397.

Stuiver, M. and Pearson, G.W, 1986. High-precision calibration of the radiocarbon time scale, AD 1950-500 BC. Radiocarbon, 28(2b): 805-838.

Vallance, J.W., Johns, G.W., Rose Jr., W.I. and Conway, F.M., 1989. Eruptive history of Cerro Quemado volcano, Guatemala. Eos, Trans. Am. Geophys. Union, 70(43): 1413.

Vallance, J.W., 1994. Postglacial lahars and potential volcanic hazards in the White Salmon River drainage basin on the southwestern side of Mount Adams, Washington. U.S. Geol. Surv., Open - File Rep., 94-440, 51 pp.

Vessell, R.K. and Davies, D.K., 1981. Nonmarine sedimentation in an active fore arc basin. In: F.G. Ethridge and R.M. Flores (Editors), Recent and Ancient Nonmarine Depositional Environments, Models for Exploration. Soc. Econ. Paleontol. Mineral., Spec. Publ., 31: 31-45.

Voight, B., 1992. Causes of landslides: conventional factors and special considerations for geothermal sites and volcanic regions. Geotherm. Resour. Counc. Trans., 16: 529-533.

Voight, B., Glicken, H., Janda, R.J. and Douglass, P.M., 1981. Catastrophic rockslide avalanche of May 18. In: P.W. Lipman and D.R. Mullineaux (Editors), The 1980 Eruptions of Mount St. Helens, Washington. U.S. Geol. Surv., Prof. Pap., 1250: 379400 .

Voight, B., Janda, R.J., Glicken, H. and Douglass, P.M., 1983. Nature and mechanics of the Mount St. Helens rock-slide avalanche of 18 May 1980. Geotechnique, 33: 243-273.

White, S.E. and Valastro Jr., S., 1984. Pleistocene glaciation of volcano Ajusco, Central Mexico, and comparison with the standard Mexican sequence. Quat. Res., 21: 21-35.

Williams, S.N. and Self, S., 1983. The October 1902 plinian eruption of Santa María Volcano, Guatemala. J. Volcanol. Geotherm. Res., 16: 33-56. 